\title{
Aurifilum, a new fungal genus in the Cryphonectriaceae from Terminalia species in Cameroon
}

\author{
Aime Didier B. Begoude ${ }^{1,2}$, Marieka Gryzenhout ${ }^{1}$, Michael J. Wingfield ${ }^{1}$ and Jolanda Roux $^{1}$
}

(1) Department of Microbiology and Plant Pathology, Forestry and Agricultural Biotechnology Institute (FABI), University of Pretoria, Pretoria, 0002, South Africa

(2) Laboratoire Régional de Lutte Biologique et de Microbiologie Appliquée, Institut de la Recherche Agricole pour le Développement (IRAD), Nkolbisson, BP 2067, Yaounde, Cameroun

\author{
Aime Didier B. Begoude \\ Email: didier.begoude@fabi.up.ac.za \\ Email: dbegoude@yahoo.fr
}

\begin{abstract}
Native Terminalia spp. in West Africa provide a popular source of construction timber as well as medical, spiritual and social benefits to rural populations. Very little is, however, known regarding the diseases that affect these trees. During an investigation into possible diseases of Terminalia spp. in Cameroon, orange to yellow fungal fruiting structures, resembling those of fungi in the Cryphonectriaceae, were commonly observed on the bark of native Terminalia ivorensis, and on dead branches of non-native Terminalia mantaly. In this study the fungus was identified based on morphological features as well as DNA sequence data (ITS and $\beta$-tubulin) and its pathogenicity was tested on T. mantaly seedlings. Our results showed that isolates of this fungus represent a previously undescribed genus in the Cryphonectriaceae, which we describe as Aurifilum marmelostoma gen. et sp. nov. Pathogenicity tests revealed that A. marmelostoma is pathogenic on $T$. mantaly. These tests, and the association of $A$. marmelostoma with disease symptoms on $T$. ivorensis, suggest that the fungus is a pathogen of this important tree.
\end{abstract}

\section{Introduction}

The Cryphonectriaceae (Diaporthales) was described to include fungi belonging to the Cryphonectria-Endothia complex (Gryzenhout et al. 2006a). These fungi are characterized by a Diaporthe-type centrum and orange stromatic tissue in culture and on host tissue, as well as biochemical properties such as a pigment reaction with $3 \% \mathrm{KOH}$ and lactic acid. While morphological features, such as the degree of development, type and color of stromatic tissues, color and length of perithecial necks, color and shape of conidiomata and ascospore septation are used to distinguish genera in the Cryphonectriaceae, species differentiation is primarily based on spore shape and size (Micales and Stipes 1987; Gryzenhout et al. 2009).

Ten genera have been described in the Cryphonectriaceae (Gryzenhout et al. 2009; Lumbsch and Huhndorf 2007), of which some, such as Chrysoporthe and Cryphonectria, accommodate virulent tree pathogens. For example, Cryphonectria parasitica is best known as the causal agent of chestnut blight that has devastated American chestnut trees (Castanea dentata) in North America (Anagnostakis 1987, 2001) and Europe (Heiniger and Rigling 1994). Examples of well-known pathogens in Chrysoporthe include Chr. austroafricana and Chr. cubensis (Gryzenhout et al. 2004) that have had a serious negative impact on Eucalyptus plantations in the tropics and subtropics, 
causing stem cankers and tree death (Hodges 1980; Wingfield 2003).

Species in the Cryphonectriaceae have a worldwide occurrence and their hosts include native and introduced tree species (Gryzenhout et al. 2009). Although the total inventory of trees susceptible to infection by the Cryphonectriaceae is incomplete, more than 100 tree species in over 14 families have been reported as hosts (Gryzenhout et al. 2009). In Africa, the Cryphonectriaceae are well known on trees in the Myrtales. Hosts recorded include Eucalyptus spp. and Syzygium spp. (Myrtaceae) (Gibson 1981; Heath et al. 2006; Nakabonge et al. 2006a), Heteropyxis canescens (Heteropyxidaceae) (Nakabonge et al. 2006a), Tibouchina spp. (Melastomataceae) (Myburg et al. 2002; Nakabonge et al. 2006a) and Terminalia ivorensis (Combretaceae) (Ofosu-Asiedu and Cannon 1976). These plants occur naturally (Syzygium spp., H. canescens, T. ivorensis), are grown as a source of pulp and timber (Eucalyptus spp. and T. ivorensis) or are non-native species grown as ornamentals (Tibouchina spp.).

In West Africa, native species of Terminalia, such as T. ivorensis and T. superba are important for forestry. Timber products from $T$. ivorensis and $T$. superba are commercially popular and ranked third in the national round wood export business in Cameroon (Laird 1999). Moreover, they are widely grown as a plantation crop where they are established by direct planting or in the "taungya" system where food crops are grown together with them (Lamb and Ntima 1971; Norgrove and Hauser 2002). Various species of Terminalia also provide medical, spiritual and social benefits to rural people (Batawila et al. 2005; Kamtchouing et al. 2006; Thiombiano et al. 2006).

Despite the economic and sociological importance of Terminalia spp., little research has been conducted on the fungal diseases affecting these trees (Ofosu-Asiedu and Cannon 1976; Hodges and Ferreira 1981; Gryzenhout et al. 2005; Kamgan et al. 2008). As part of a larger project investigating diseases that affect Terminalia spp. in Africa, a survey was undertaken in Cameroon. Distinctive fungi with orange to yellow ascostromata resembling those of the Cryphonectriaceae were commonly observed in the bark of standing native T. ivorensis, and on dead branches of nonnative T. mantaly. The objective of this study was to use DNA sequence and morphological comparisons to provide a taxonomic placement for this fungus. Furthermore, pathogenicity trials were performed to assess its potential ecological significance.

\section{Materials and Methods}

\section{Survey and specimen collection}

Surveys were conducted in the central and southern parts of Cameroon in December 2007. These regions are located in the fifth agro-ecological zone of the country (http://www.iradcameroon.org/carte_us.php) where the vegetation and climatic conditions are characterized by humid forests with bimodal rainfall and relatively high temperatures, averaging $26^{\circ} \mathrm{C}$. At the collection sites, native T. ivorensis is grown in plantations while T. mantaly is planted as ornamentals alongside city roads and in villages. Bark segments bearing fungal fruiting bodies were collected from trees showing signs of disease and transported to the laboratory.

For isolation, the ascostromata on the bark were cut horizontally with a scalpel under a dissecting microscope and ascospore masses were extracted with a sterile needle and transferred onto $2 \%$ malt extract agar (MEA) (2\% malt extract, 1.5\% agar; Biolab, Merck, Midrand, Johannesburg, S.A.). Single germ tubes developing from the spores were transferred to fresh Petri dishes containing MEA and incubated at $25^{\circ} \mathrm{C}$. Pure cultures were deposited in the Culture Collection (CMW) of the Forestry and Agricultural Biotechnology Institute (FABI), University of Pretoria, Pretoria, South Africa. Duplicates of key isolates were also deposited with the Centaalbureau voor Schimmelcultures (CBS, Utrecht, Netherland), while bark specimens bearing fruiting bodies were 
deposited with the National Collection of Fungi, Pretoria, South Africa (PREM).

\section{DNA sequence comparisons}

Mycelium was scraped from the surfaces of 10-day-old cultures of five isolates with a sterile scalpel and transferred to $1.5 \mu 1$ Eppendorf tubes for freeze-drying. The freeze-dried mycelium was ground to a fine powder by shaking for $2 \mathrm{~min}$ at $30.01 \mathrm{~s}^{-1}$ frequency in a Retsch cell disrupter (Retsch Gmbh, Germany) using $2 \mathrm{~mm}$-diameter metal beads. Total genomic DNA was extracted following the method of Möller et al. (1992) and the concentration of the resulting DNA was determined on a NanoDrop (ND-1000 uv/Vis spectrometer, NanoDrop Technologies, Wilmington, DE USA) version 3.1.0.

The oligonucleotide primer pairs ITS1 (5' TCCGTAGGTGAACCTGCGG 3') and ITS4 (5' TCCTCCGCTTATTGATATGC 3') (White et al. 1990), Bt1A (5' TTCCCCCGTC TCCACTTCTTCATG 3') and Bt1B (5' GACGAGATCGTTCATGTTGAACTC 3'), Bt2A (5' GGTAACCAAATCGGTGCTGCTTT C $3^{\prime}$ ) and Bt2B (5' ACCCTCAGTGTAGTGACC CTTGGC $3^{\prime}$ ) (Glass and Donaldson 1995) were used to amplify and sequence the internal transcribed spacer (ITS) regions (including the complete 5.8S) and the $\beta$-tubulin 1 and 2 ( $\beta$-tub) gene regions respectively. A "hot start" polymerase chain reaction (PCR) was carried out in an Icycler thermal cycler (BIO-RAD, Hercules, CA, USA) to amplify a $25 \mu$ PCR reaction mixture containing $0.5 \mu 1$ of each primer $(10 \mathrm{mM}), 2.5 \mu \mathrm{dNTPs}(10 \mathrm{mM}), 4 \mu \mathrm{l}$ of $10 \mathrm{mM} \mathrm{MgCl}_{2}, 2.5 \mu \mathrm{l}$ of $10 \mathrm{mM}$ reaction buffer ( $25 \mathrm{mM}), 1 \mathrm{U}$ of Taq polymerase (Roche Diagnostics GmbH, Mannheim, Germany), 60-100 $\mathrm{ng} / \mu \mathrm{l}$ of DNA and $13.5 \mu \mathrm{l}$ of sterile SABAX water. The amplification conditions were an initial denaturation at $96^{\circ} \mathrm{C}$ for $1 \mathrm{~min}$, followed by 35 cycles of $30 \mathrm{~s}$ at $94^{\circ} \mathrm{C}$, annealing for $1 \mathrm{~min}$ at $54^{\circ} \mathrm{C}$, extension for $90 \mathrm{~s}$ at $72^{\circ} \mathrm{C}$ and a final elongation step of $10 \mathrm{~min}$ at $72^{\circ} \mathrm{C}$. The PCR amplification products were separated by electrophoresis on $2 \%$ agarose gels stained with ethidium bromide in a $1 \times$ TAE buffer and visualized under UV light.

The amplified PCR fragments were cleaned using 6\% Sephadex G-50 fine mini spin-columns (Sigma, Steinhein, Germany) following the manufacturer's instructions. Thereafter, 25 amplification cycles were carried out for each sample on an Icycler thermal cycler to generate sequences in both the forward and reverse directions using $10 \mu \mathrm{l}$ mixes. Each mix contained $1 \mu \mathrm{l}$ reaction buffer, $2 \mu \mathrm{l}$ ready reaction buffer (Big dye), $1 \mu \mathrm{l}$ primer $(10 \mathrm{mM}), 3 \mu \mathrm{l}$ of the PCR product and $3 \mu \mathrm{l} \mathrm{Sabax}$ water. The reaction cycles had the following parameters: one step at $96^{\circ} \mathrm{C}$ for denaturation of the double stranded DNA $(10 \mathrm{~s})$, followed by an annealing step at $50^{\circ} \mathrm{C}(5 \mathrm{~s})$ and primer extension at $60^{\circ} \mathrm{C}(4 \mathrm{~min})$. The BigDye Terminator v 3.1 Cycle sequencing Kit (PE Applied Biosystems) was used for sequencing reactions, following the manufacturer's protocols, on an ABI PRISM $3130 \times 1$ genetic analyzer using Pop 7 polymer (Applied Biosystems, Foster City, California, USA).

The sequences of the isolates from Terminalia spp. were edited using MEGA version 4 (Tamura et al. 2007). For the phylogenetic analyses, DNA sequences from this study were compiled into a matrix using the dataset produced by Gryzenhout et al. (2009) as a template (TreeBase number: S2003 Matrix M3737). The matrix was aligned using MAFFT (http://align.bmr.kyushuu.ac.jp/mafft/online/server/) version 6 (Katoh et al. 2005). The aligned sequences were transferred to PAUP version 4.0b10 (Swofford 1998) where a final manual alignment was made.

Phylogenetic analyses were run for each of the gene region datasets separately, as well as for a combined ITS and $\beta$-tub data set. In the analyses, gaps were treated as a fifth character (NEWSTATE) and all characters were unordered and of equal weight. The phylogenetic analyses for all the datasets were performed using the maximum parsimony (MP) option, with trees generated by heuristic searches with random stepwise addition in 1000 replicates, tree bisection and 
reconnection (TBR) as branch swapping algorithm, and random taxon addition for the construction of MP trees. Branches of zero length were collapsed and all multiple, equally parsimonious trees were saved. MAXTREES was set to auto-increase in all analyses. Sequences of two isolates of Diaporthe ambigua (Gryzenhout et al. 2009), which belong to the Diaporthaceae, another family in the Diaporthales (Castlebury et al. 2002; Rossman et al. 2007), were used as outgroups in all analyses, following examples of previously published data sets (Gryzenhout et al. 2009). The outgroup was monophyletic in the phylogenetic analyses. The support of the branches for the most parsimonious trees was assessed with a 1000 bootstrap replications (Felsenstein 1985). Other measures noted were tree length, consistency index, rescaled consistency index, and retention index (Hillis and Huelsenbeck 1992). A partition homogeneity test of 500 replicates was conducted in PAUP to assess the possibility of combining the ITS and $\beta$-tub data sets.

Bayesian analyses using the Markov Chain Monte Carlo (MCMC) method were performed to ascertain the topology of trees obtained with PAUP. Before launching the Bayesian analyses, the best nucleotide substitution models for each dataset were separately determined with MrModelTest version 2.2 (Nylander 2004) and included in each partition in MrBayes v3.1.2. (Huelsenbeck and Ronquist 2001). HKY $+\mathrm{I}+\mathrm{G}$ were chosen as best-fitting model for both the ITS and $\beta$-tub datasets. The MCMC analyses, with four chains, started from random tree topology and lasted one million generations. Trees were saved every 100th generation. The burn-in number was graphically estimated from the likelihood scores and trees outside this point were discarded in the analyses. The consensus trees were constructed in MEGA version 4 and posterior probabilities were assigned to branches after $50 \%$ majority rule.

\section{Morphology}

A small piece of an original bark specimen bearing fruiting structures from which the fungal isolates were obtained was cut and boiled in water for $1 \mathrm{~min}$ to rehydrate the cells (Myburg et al. 2004; Gryzenhout et al. 2005). The structures were then broken from the bark and sections (12 $\mu \mathrm{m}$ thick) were made with a Leica CM1100 cryostat (Setpoint Technologies, Johannesburg, South Africa) at $-20^{\circ} \mathrm{C}$. Sections were mounted on microscope slides in $85 \%$ lactic acid. Stromata were also crushed on microscope slides in $3 \% \mathrm{KOH}$ in order to study the asci, ascospores, conidia, conidiophores and conidiogenous cells. Morphological features of fruiting bodies were photographed with a HRc Axiocam and accompanying Axiovision 3.1 software (Carl Zeiss Ltd., München, Germany). For the holotype specimen, 50 measurements of each structure mentioned above were taken, whereas 20 measurements were made for the paratypes. These measurements were recorded as the extreme in brackets and the range calculated as the mean of the overall measurements plus and minus the standard deviation.

The physiognomy of fungal colonies was described from cultures grown on $2 \% \mathrm{MEA}$ at $25^{\circ} \mathrm{C}$ under near UV-light for 2 weeks. Colony colours of the isolates were recorded using the color notations of Rayner (1970). Growth studies for isolates growing on 2\% MEA in the dark was performed by measuring the daily growth at $5^{\circ} \mathrm{C}$ intervals ranging from 10 to $35^{\circ} \mathrm{C}$ for five replicates of two isolates (ex-holotype isolate CMW28290, ex-paratype isolate CMW28285).

\section{Pathogenicity}

Seedlings of native species of Terminalia were not available for pathogenicity tests and these were consequently performed only on non-native $T$. mantaly trees. Pathogenicity experiments were carried out on 1-year-old T. mantaly plants grown in the Yaoundé Urban Council nursery, Cameroon. The trees were maintained in $15 \mathrm{~cm}$ diameter plastic bags and watered daily. At the time of inoculation, the average stem diameter of the trees was approximately $10 \mathrm{~mm}$. For inoculations, isolates were grown on $2 \%$ MEA for 10 days prior to inoculation. 
To inoculate trees, wounds were made on the stems, $\sim 10 \mathrm{~cm}$ above soil level, by removing the outer bark with a $5 \mathrm{~mm}$ diameter cork-borer. A $5 \mathrm{~mm}$-diameter plug bearing mycelium of each isolate was placed into each wound, with the mycelium facing the cambium, and wrapped with a strip of Parafilm (Pechiney Plastic Packaging, Chicago, USA) to prevent desiccation and cross contamination. The trees were divided into two separate blocks and within each block, six trees arranged in a completely randomized design, were used for each isolate. The entire trial was repeated once. For the control inoculations, a sterile MEA plug was used. After 6 weeks, the lengths of the lesions in the cambium were measured to obtain an indication of the virulence of the isolates tested. Single fruiting bodies were removed from the necrotic tissue and these were placed on MEA to produce cultures and to confirm the cause of the lesions. As no significant differences were noticed between the two pathogenicity tests $(\mathrm{P}>0.05)$, the data for all isolates were pooled in a single dataset for analyses. Variation in lesion lengths was assessed through a one-way analysis of variance (ANOVA) using SAS (SAS systems, version 8.2; SAS Institute).

\section{Results}

\section{Survey and specimen collection}

Terminalia trees at three sites, in two regions, in southern and central Cameroon were inspected. A total of seven trees were found with fruiting bodies of the unknown fungus. On living standing $T$. ivorensis, disease symptoms included cankers on the tree trunks (Fig. 1a), cracked bark containing yellow to orange fruiting structures (Fig. 1b) and necrotic cambium including dead wood. On $T$. mantaly, cankers covered with abundant fruiting bodies were observed on the trunks of dead trees and on senescing branches (Fig. 1c). Samples were obtained from one T. mantaly tree in Yaoundé, five T. ivorensis trees in Mbalmayo in the Central Region, and one T. mantaly tree in Kribi in the Southern Region of Cameroon (Fig. 2).

\section{DNA sequence comparisons}

Five isolates resembling the Cryphonectriaceae, collected from Terminalia spp. in Cameroon, were selected for DNA sequencing (Table 1). Sequencing resulted in fragments of $\sim 600 \mathrm{bps}$ for the ITS and $\sim 550$ bps for each of the $\beta$-tub gene regions. BLAST searches against the NCBI (www.blast.ncbi.nlm.nih.gov) data base confirmed that the isolates collected represented species in the Cryphonectriaceae and indicated that isolates from Cameroon were most closely related to Microthia havanensis.

Data sets containing ITS and $\beta$-tub sequences were compiled using sequences obtained from isolates of Cryphonectriaceae in Cameroon and those obtained from Gryzenhout et al. (2009). These data sets comprised a total of 36 isolates each (Table 1), five isolates obtained from Terminalia spp. and 31 sequences that were used in the monograph of the Cryphonectriaceae (Gryzenhout et al. 2009) that represents the most complete database of sequences for this family.

Of the 592 characters present in the ITS data set, 250 were parsimony-informative. The MP analyses generated 60 identical trees $(\mathrm{TL}=568, \mathrm{CI}=0.697, \mathrm{RI}=0.876, \mathrm{RC}=0.611)$. Isolates from Terminalia spp. grouped in a single, well supported clade, distinct from all other recognized genera of the Cryphonectriaceae. A consensus tree generated through Bayesian analyses of the ITS data confirmed the uniqueness of the isolates from Cameroon. 

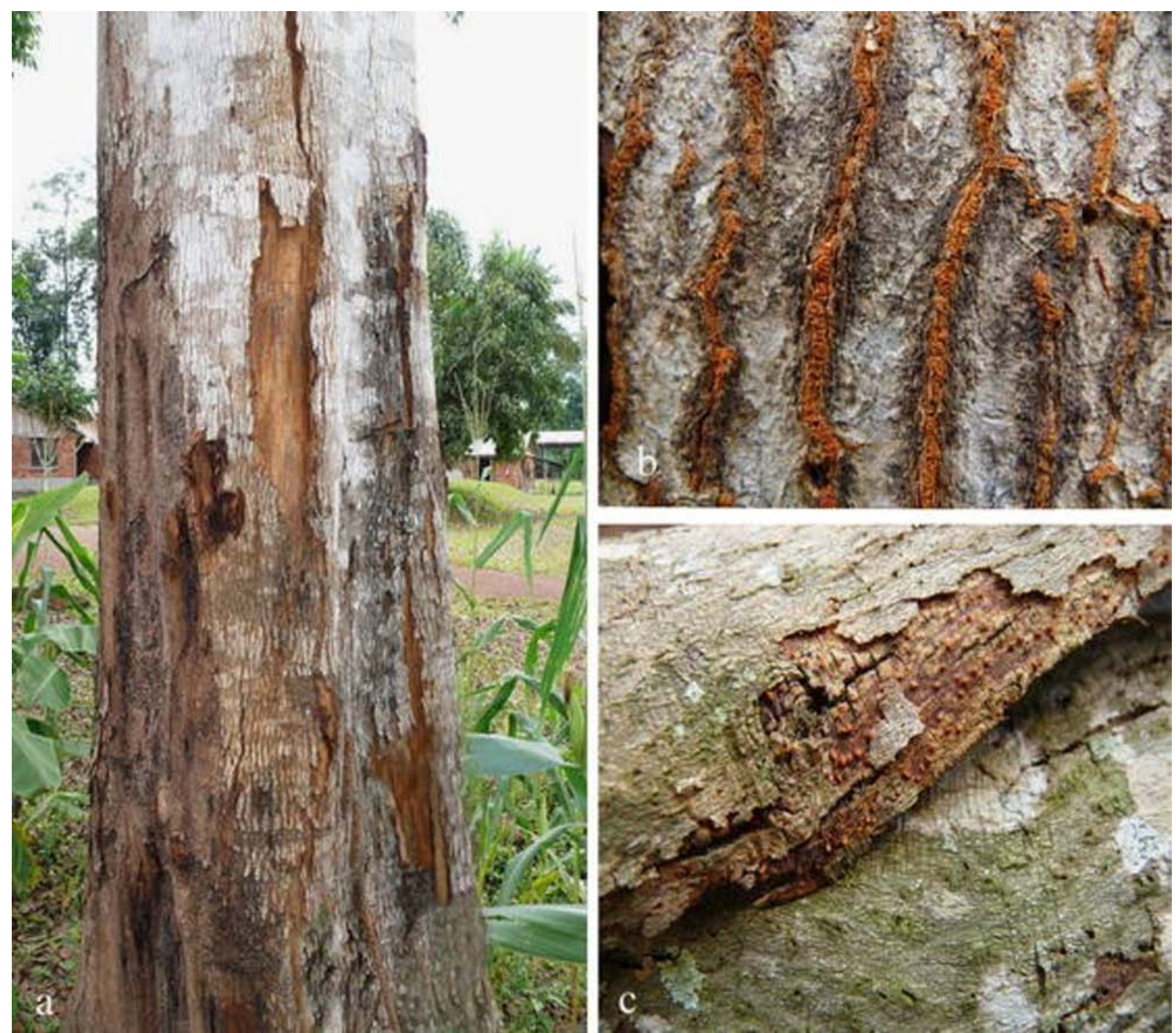

Fig. 1. Symptoms of infection by Aurifilum marmelostoma on Terminalia spp. in Cameroon. a canker on the basal parts of a Terminalia ivorensis trunk; $\mathbf{b}$ bark cracks containing yellow to orange fruiting structures; c orange stromata on bark of Terminalia mantaly.

In the analyses of the $\beta$-tub data set, sequences consisted of 991 characters with 486 parsimony informative characters of which 316 came from ambiguous portions representing introns (one for the $\beta$-tub 1 and two for the $\beta$-tub 2 gene region). The MP analyses yielded four most parsimonious trees $(\mathrm{TL}=1382, \mathrm{CI}=0.614, \mathrm{RI}=0.834, \mathrm{RC}=0.512)$. The tree generated from the $\beta$-tub data (figure not shown) also separated the isolates from Terminalia spp. into a well supported clade, distinct from all the known genera in the Cryphonectriaceae. The tree obtained after Bayesian analyses confirmed results obtained from the MP analyses, suggesting that isolates from Cameroon represent a distinct genus and species. In a separate analysis of $\beta$-tub sequences without the ambiguous portions representing the introns (384 characters), a similar tree topology with high statistical support was obtained (tree not shown). However, the analysis of $\beta$-tub sequences containing the introns were preferred as it provided more informative characters. Concordance among the ITS and $\beta$-tub datasets was confirmed by the results of the partition homogeneity test $(\mathrm{P}=0.002)$ suggesting a lack of conflict between these gene genealogies, and they were thus combined. A total of 1583 bases were generated for the combined ITS and $\beta$-tub data sets. Of these, 735 characters were parsimony informative. After heuristic searches, one most parsimonious tree of 1980 steps $(\mathrm{CI}=0.628, \mathrm{RI}=0.839, \mathrm{RC}=0.527$; TreeBase Accession No: SN4451) was obtained (Fig. 3). The consensus tree obtained from the combined analysis of ITS and $\beta$-tub sequences showed that isolates of the unknown fungus from Terminalia spp. formed a well 
supported clade (Bayesian Posterior Probability (BPP)/Bootstrap support (BS): 1/100). This clade is distinct from other phylogenetically related genera in the Cryphonectriaceae (Gryzenhout et al. 2009).
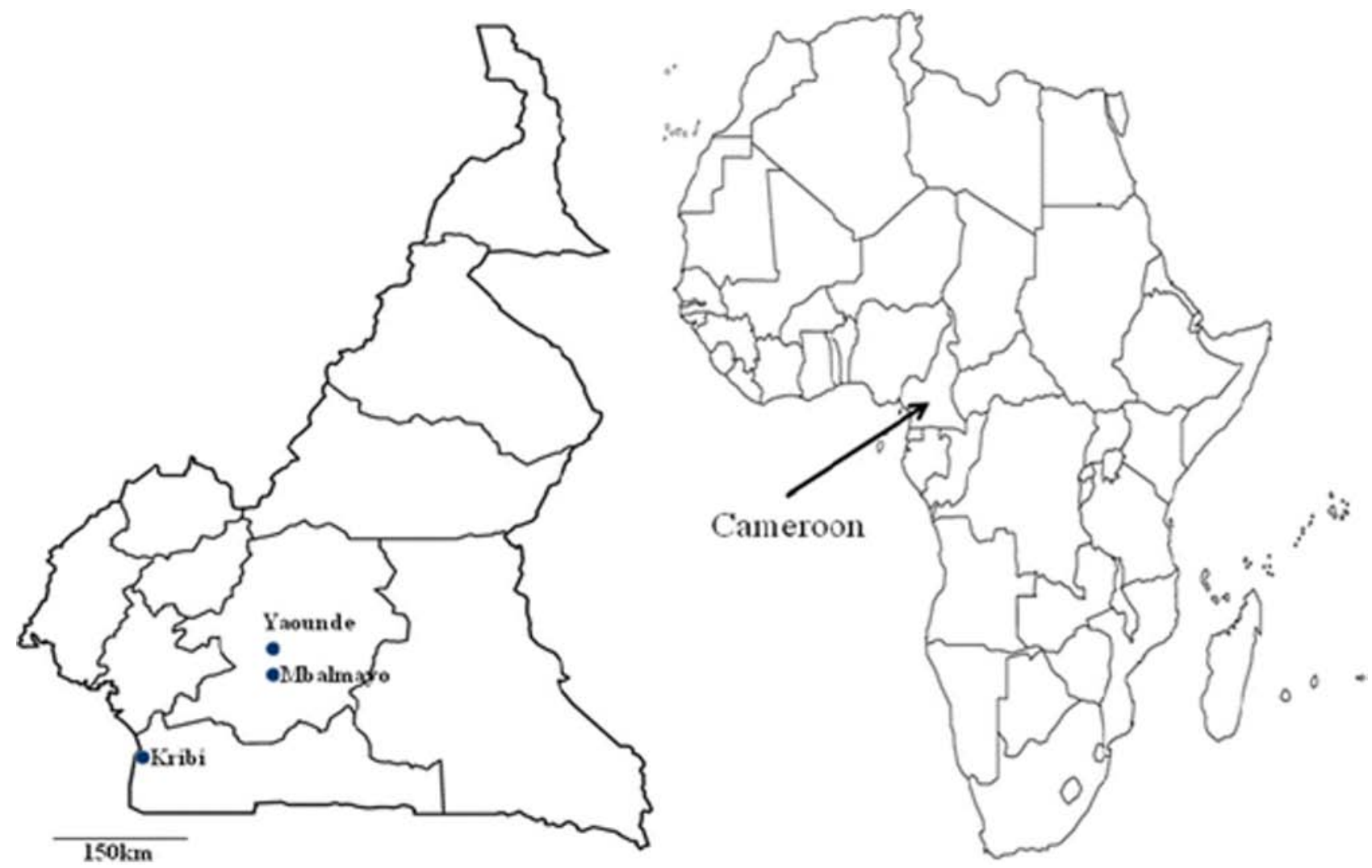

Fig. 2. Map of Cameroon showing sites where Aurifilum marmelostoma was collected from Terminalia ivorensis and Terminalia mantaly.

\section{Morphology}

Consistent with DNA sequence data, the fruiting bodies from Terminalia spp. showed typical microscopic characteristics of members of the Cryphonectriaceae (Table 2). These fruiting structures were characterized by distinct orange stromatic tissue, Diaporthe-type centra (Gryzenhout et al. 2006a) and a pigment that turns purple and yellow in culture and host tissue when treated with 3\% KOH and lactic acid respectively (Castlebury et al. 2002; Rossman et al. 2007; Gryzenhout et al. 2009). The teleomorph fruiting structures were abundant on the bark, while conidiomatal structures were only occasionally seen on the bark specimens.

The fungus on Terminalia spp. in Cameroon resembled those species in the Cryphonectriaceae that have uniformly orange fruiting bodies as opposed to those with different colors between their anamorph and teleomorph states, such as species of Chrysoporthe (Gryzenhout et al. 2009). However, it had a number of features distinguishing it from all other Cryphonectriaceae. The most obvious of these characteristics were present in the anamorph. Conidiomata of the fungus from Cameroon were broadly convex, and thus wider than similar structures of Amphilogia and Rostraureum (Table 2). The presence of darkened ostiolar openings at the apex of the conidiomata was also unique to the fungus. Long paraphyses, or seemingly sterile cells $(<90 \mu \mathrm{m})$ (Walker et al. 1985; Venter et al. 2002), were observed between conidiophores, similar to those found for conidiomata of Holocryphia and Microthia (Gryzenhout et al. 2006b). 
Table 1. Isolates of the Cryphonectriaceae used in this study.

\begin{tabular}{|c|c|c|c|c|c|}
\hline Species & $\begin{array}{l}\text { Isolates } \\
\text { number }\end{array}$ & Host & Origin & Collector & $\begin{array}{l}\text { Genbank accession } \\
\text { numbers }\end{array}$ \\
\hline \multirow[t]{2}{*}{ Amphylogía gyrosa } & CMW 10469 & $\begin{array}{l}\text { Ehececapus } \\
\text { densalus }\end{array}$ & New Zealand & GJ. Samuels & $\begin{array}{l}\text { AF452111, AF525707, } \\
\text { AF525714 }\end{array}$ \\
\hline & CMW 10740 & E. dentalss & New Zealand & GJ. Samuels & $\begin{array}{l}\text { AF452112, AF525708, } \\
\text { AF525715 }\end{array}$ \\
\hline \multirow[t]{2}{*}{ Aurapex penicallasa } & CMW 10030 & Miconia theazeans & Colombia & C.A. Rodas & $\begin{array}{l}\text { AY214311, AY214239, } \\
\text { AY214275 }\end{array}$ \\
\hline & CMW 10035 & M. theazeans & Colombia & C.A. Rodas & $\begin{array}{l}\text { AY214313, AY214241, } \\
\text { AY214277 }\end{array}$ \\
\hline \multirow[t]{5}{*}{$\begin{array}{l}\text { Auriffum } \\
\text { marmelostoma }\end{array}$} & $\begin{array}{l}\text { CMW } \\
28285\end{array}$ & Termindia mansaly & Cameroon & D. Begoude and J. Roux & $\begin{array}{l}\text { FJ882855, FJ900685, } \\
\text { FJ900690 }\end{array}$ \\
\hline & $\begin{array}{l}\text { CMW } \\
28288\end{array}$ & T. ivonensis & Cameroon & D. Begoude and J. Roux & $\begin{array}{l}\text { FJ } 882856 \text {, FJ900686, } \\
\text { FJ900691 }\end{array}$ \\
\hline & $\begin{array}{l}\text { CMW } \\
28289\end{array}$ & T. horensis & Cameroon & D. Begoude and J. Roux & $\begin{array}{l}\text { FJ890495, FJ900687, } \\
\text { FJ900692 }\end{array}$ \\
\hline & $\begin{array}{l}\text { CMW } \\
28290\end{array}$ & T. ivorensis & Cameroon & D. Begoude and J. Roux & $\begin{array}{l}\text { FJ890496, FJ900688, } \\
\text { FJ900693 }\end{array}$ \\
\hline & $\begin{array}{l}\text { CMW } \\
28592\end{array}$ & T. mantaly & Camerocn & D. Begoude and J. Roux & $\begin{array}{l}\text { FJ } 890497, \text { FJ900689, } \\
\text { FJ900694 }\end{array}$ \\
\hline \multirow[t]{2}{*}{ Celoparthe dispena } & CMW 9976 & Syzygiton cordatum & South Africa & M. Gryzenhou & $\begin{array}{l}\text { DQ267130, DQ267136, } \\
\text { DQ267142 }\end{array}$ \\
\hline & CMW 9978 & S. cordation & South Africa & M. Gryzenhout & $\begin{array}{l}\text { AY214316, DQ267135, } \\
\text { DQ267141 }\end{array}$ \\
\hline \multirow[t]{2}{*}{$\begin{array}{l}\text { Chrysoporthe } \\
\text { aussroafricana }\end{array}$} & CMW 2113 & Eucalypeus grandis & South Africa & MJ. Wingfield & $\begin{array}{l}\text { AF046892, AF273067, } \\
\text { AF273462 }\end{array}$ \\
\hline & CMW 9327 & $\begin{array}{l}\text { Tibouchina } \\
\text { granubsa }\end{array}$ & South africa & MJ. Wingfield & $\begin{array}{l}\text { AF273473, AF273060, } \\
\text { AF273455 }\end{array}$ \\
\hline \multirow[t]{2}{*}{ Chrysoporghe cubensis } & CMW 10639 & Eucalypeus grandis & Colombia & C.A. Rodss & $\begin{array}{l}\text { AY263419, AY263420, } \\
\text { AY263421 }\end{array}$ \\
\hline & CMW 10669 & Eucalypeus sp. & $\begin{array}{l}\text { Republic of } \\
\text { Congo }\end{array}$ & J. Roux & $\begin{array}{l}\text { AF535122, AF535124, } \\
\text { AF535126 }\end{array}$ \\
\hline \multirow[t]{2}{*}{$\begin{array}{l}\text { Chrysoporthe III } \\
\text { hodgesiana }\end{array}$} & CMW 10625 & $\begin{array}{l}\text { Thbuchina } \\
\text { semilecandra }\end{array}$ & Colombia & R. Arbelsez & $\begin{array}{l}\text { AY } 956970, \text { AY } 966979, \\
\text { AY } 956980\end{array}$ \\
\hline & CMW 10641 & T. semilecandra & Colombia & R. Arbelaez & $\begin{array}{l}\text { AY } 692322, \text { AY } 692326, \\
\text { AY } 692325\end{array}$ \\
\hline \multirow[t]{2}{*}{$\begin{array}{l}\text { Cryphanectria } \\
\text { parasitica }\end{array}$} & CMW 7048 & Quercus vaginiana & USA & F.F. Lombard & $\begin{array}{l}\text { AF368330, AF273076, } \\
\text { AF2 } 73470\end{array}$ \\
\hline & CMW 13749 & Cassanea mollisima & Japsan & Unknown & $\begin{array}{l}\text { AY } 697927, \text { AY } 697943, \\
\text { AY } 697944\end{array}$ \\
\hline \multirow[t]{2}{*}{$\begin{array}{l}\text { Cryphonectria } \\
\text { japonica }\end{array}$} & CMW 13742 & $\begin{array}{l}\text { Quercus } \\
\text { gros.esernata }\end{array}$ & Japen & T. Kobayashi & $\begin{array}{l}\text { AY } 697936, \text { AY } 697961, \\
\text { AY } 697962\end{array}$ \\
\hline & CMW 13747 & Q. serrasa & Japan & T. Kobayashi & $\begin{array}{l}\text { AY } 697937, \text { AY } 697963, \\
\text { AY } 697964\end{array}$ \\
\hline \multirow[t]{2}{*}{ Cryhonectria radicalis } & CMW 10455 & Cassanea dendata & Italy & A. Biraghi & $\begin{array}{l}\text { AF452113, AF525705, } \\
\text { AF525712 }\end{array}$ \\
\hline & CMW 10477 & Quercus suber & Italy & M. Orsenigo & $\begin{array}{l}\text { AF368328, AF368347, } \\
\text { AF368346 }\end{array}$ \\
\hline Crypsodiaporthe corni & CMW 10526 & Cornes alterngfolsa & USA & S. Redlin & $\begin{array}{l}\text { DQ120762, DQ120769, } \\
\text { DQ120770 }\end{array}$ \\
\hline \multirow[t]{2}{*}{ Diaporthe ambigua } & CMW 5288 & Mahas domestica & South Africa & W.A Smit & $\begin{array}{l}\text { AF543817, AF543819, } \\
\text { AF543821 }\end{array}$ \\
\hline & CMW 5587 & M. domestica & South Africa & W.A. Smit & $\begin{array}{l}\text { AF543818, AF543820, } \\
\text { AF543822 }\end{array}$ \\
\hline \multirow[t]{2}{*}{ Endothia gyrosa } & CMW 2091 & Quercus podustris & USA & RJ.Stipes & $\begin{array}{l}\text { AF046906, AF368337, } \\
\text { AF368336 }\end{array}$ \\
\hline & CMW 10442 & Q. palustris & USA & RJ.Stipes & $\begin{array}{l}\text { AF368326, AF368339, } \\
\text { AF368338 }\end{array}$ \\
\hline \multirow[t]{2}{*}{ Holocryphia eucalypti } & CMW 7036 & Eucalypeas sp. & South Africa & L. van der Westhuizen & $\begin{array}{l}\text { AF232878, AF368341, } \\
\text { AF368340 }\end{array}$ \\
\hline & CMW 7037 & $\begin{array}{l}\text { Excalypeus } \\
\text { delegasensis }\end{array}$ & Australia & K.M. Old & $\begin{array}{l}\text { AF232880, AF368343, } \\
\text { AF368342 }\end{array}$ \\
\hline \multirow[t]{2}{*}{ Microthis havanensis } & CMW 14550 & Eucalypess saligna & Mexico & C.S. Hodges & $\begin{array}{l}\text { DQ368735, DQ368741, } \\
\text { DQ368742 }\end{array}$ \\
\hline & CMW 11301 & Myrica faya & Azores & $\begin{array}{l}\text { C.S. Hodges and DE. } \\
\text { Gardner }\end{array}$ & $\begin{array}{l}\text { AY214323, AY214251, } \\
\text { AY214287 }\end{array}$ \\
\hline \multirow[t]{2}{*}{ Rostraureum tropicale } & CMW 9971 & Termindia ivorensis & Ecusdor & MJ. Wingfield & $\begin{array}{l}\text { AY167425, AY167430, } \\
\text { AY167435 }\end{array}$ \\
\hline & CMW10796 & T. Honensis & Ecusdor & MJ. Wingfeld & $\begin{array}{l}\text { AY167428, AY167433, } \\
\text { AY167438 }\end{array}$ \\
\hline \multirow[t]{2}{*}{ Ursicul̈um fallax } & CMW 18115 & Cocoloba avijena & USA & C.S. Hodges & $\begin{array}{l}\text { DQ368756, DQ368760, } \\
\text { DQ368761 }\end{array}$ \\
\hline & CMW 18119 & C sovisera & USA & C.S. Hodges & $\begin{array}{l}\text { DQ368755, DQ368758, } \\
\text { DQ368759 }\end{array}$ \\
\hline
\end{tabular}

Lolates marked in bold represent those obtained from $T$. ivonensis and $T$. mantaly in Cameroon

a CMW Research collection of the Forestry and Agricultural Biotechnology Instituse (FABI), University of Pretoria, Pretoria, South Africa

b Accesssion numbers given as sequences from the ITS region, and two regions from the $\beta$-tubulin genes respectively 


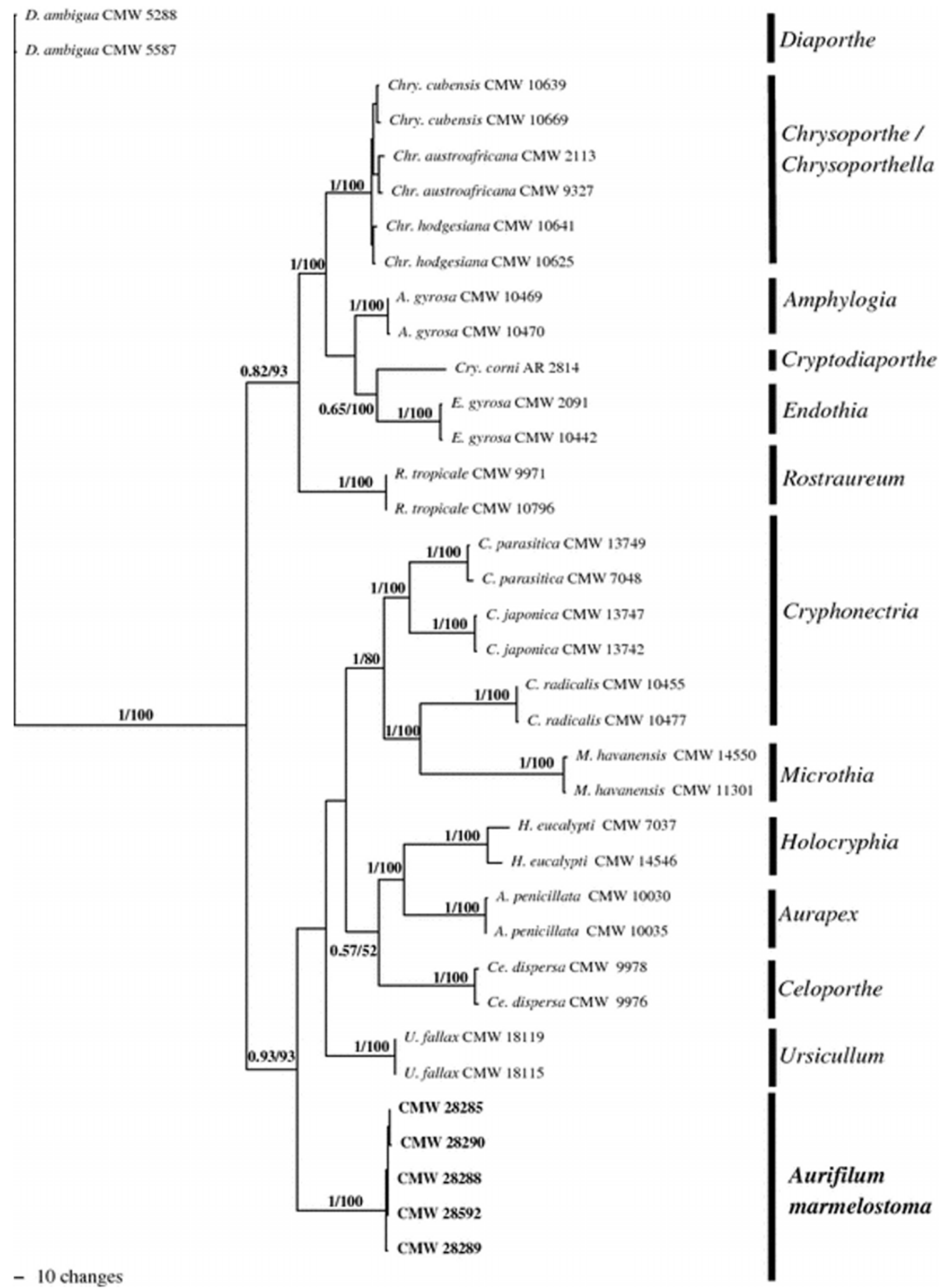

Fig. 3. Most parsimonious tree obtained from MP analyses of the combined ITS and $\beta$-tub sequence data of the Cryphonectriaceae. Posterior probabilities followed by Bootstrap support (\%) from 1000 replications are given on the branches (BPP/BS). Isolates marked in bold represent those obtained from Terminalia spp. Scale "10 changes" reflects the graphical amount of nucleotide change 
between two sequences since their divergence from the common ancestor.

Table 2. Morphological characteristics of genera in the Cryphonectriaceae with uniformly orange ascostromata, compared with those of Aurifilum.

\begin{tabular}{|c|c|c|c|c|c|c|c|c|c|}
\hline $\begin{array}{l}\text { Morpbologica } \\
\text { haraderisbie: }\end{array}$ & & Ampaliegia & Copphasectria & Endochic & Holoogphis & Microstia & Rostravesm & Vrsicullum & Axvifibem \\
\hline \multirow[t]{3}{*}{ Teleomacph } & $\begin{array}{l}\text { Studure of } \\
\text { noostromata }\end{array}$ & $\begin{array}{l}\text { Pulviaste, exumpese } \\
\text { slightly immersed } \\
\text { to superficial }\end{array}$ & $\begin{array}{l}\text { Large, pulviase, } \\
\text { esumpeas, semi. } \\
\text { immersed }\end{array}$ & 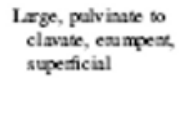 & $\begin{array}{l}\text { Pulviaxe, semi- } \\
\text { immersed }\end{array}$ & $\begin{array}{l}\text { Lrge, pal viante, } \\
\text { enumpert, semi. } \\
\text { innersed }\end{array}$ & $\begin{array}{l}\text { Pulviaate, } \\
\text { esumpex } \\
\text { immersed } \\
\text { so semi. } \\
\text { immersed }\end{array}$ & Not ksowa & $\begin{array}{l}\text { Iarge, palviante so } \\
\text { pyrifocm, semi. } \\
\text { immersed }\end{array}$ \\
\hline & $\begin{array}{l}\text { Ascospoce } \\
\text { shape }\end{array}$ & $\begin{array}{l}\text { Hyal ise, el lipssoidal } \\
\text { to fuscoid }\end{array}$ & $\begin{array}{l}\text { Hyalise, ellipooidal } \\
\text { so fuowid }\end{array}$ & Hyalise, cylisdrical & Hyalise, cylistrical & $\begin{array}{l}\text { Hyal ise, ellipooidal } \\
\text { so fuowid }\end{array}$ & $\begin{array}{l}\text { Hyalise, } \\
\text { ellipooidal } \\
\text { so fusoid }\end{array}$ & Not ksowa & $\begin{array}{l}\text { Hyaline, elliproxidal } \\
\text { so fuocid }\end{array}$ \\
\hline & $\begin{array}{r}\text { Ascospoce } \\
\text { sepation }\end{array}$ & 13 squexe & Ose sepate & Aspptate & Asepate & Ose sepexe & Ose sepate & Not bowa & Ose spptate \\
\hline \multirow[t]{4}{*}{ Aarnocph } & $\begin{array}{l}\text { Structure of } \\
\text { conidiomata }\end{array}$ & Corical, superficial & $\begin{array}{l}\text { Pulviaxe, enumes, } \\
\text { semi-imnersed }\end{array}$ & $\begin{array}{l}\text { Pul vinate, erumpex, } \\
\text { supesicial, }\end{array}$ & $\begin{array}{l}\text { Pulviaxte, erumpex, } \\
\text { semidimnersed }\end{array}$ & $\begin{array}{l}\text { Pulviante, exumpex } \\
\text { semi-immersed }\end{array}$ & $\begin{array}{l}\text { Clavate to } \\
\text { rostrate }\end{array}$ & $\begin{array}{l}\text { Pyrifoem } \propto \text { routrate, } \\
\text { supeficial }\end{array}$ & Brodly coovex \\
\hline & $\begin{array}{l}\text { Cooidiomatal } \\
\text { seck }\end{array}$ & Abocat & Abocest & Abocest & Aboest & Abocest & Preseat & Preseat & $\begin{array}{l}\text { Aboest, os bol } x \\
\text { opening darkesed }\end{array}$ \\
\hline & $\begin{array}{l}\text { Cooidiomatal } \\
\text { stromxic } \\
\text { tiwue }\end{array}$ & $\begin{array}{l}\text { Proseschyma asd } \\
\text { pseudopareschyma }\end{array}$ & $\begin{array}{l}\text { Poseschyma asd } \\
\text { poevolopreschyma }\end{array}$ & $\begin{array}{l}\text { Proseschyma asd } \\
\text { psoudopareschyma }\end{array}$ & $\begin{array}{l}\text { Poseschym asd } \\
\text { preodopreschyma }\end{array}$ & $\begin{array}{l}\text { Proseschyma asd } \\
\text { preodopareschyma }\end{array}$ & $\begin{array}{l}\text { Of differeat } \\
\text { textua } \\
\text { type }\end{array}$ & $\begin{array}{l}\text { Proueschyma asd } \\
\text { psecudopaxschyma }\end{array}$ & $\begin{array}{l}\text { Poseadyma asd } \\
\text { poevodopareschyma }\end{array}$ \\
\hline & Paraphyses & Aboest & Aboex & Abreas & Prasex & Presest & Aboese & Abseat & Presex \\
\hline
\end{tabular}

Gryzenhout et al. (2005), provided details of morphological characteristics of African specimens (IMI 187898 and IMI 288729) of Cryphonectriaceae obtained from T. ivorensis in Ghana and Kenya, respectively. The same specimens were also considered in this study. Conidiomata of the Ghanaian specimen were characterized by orange, pulvinate conidiomata without elongated necks, similar to the conidiomata of the Cameroonian specimens that are orange and broadly convex. The stromatic ascostromata of specimens from both Ghana and Kenya resemble the Cameroonian isolates. The similarity of specimens from Cameroon, Ghana and Kenya was, furthermore, supported by spore characteristics (one septate, fusoid to ellipsoid ascospores and minute, cylindrical conidia) and overlapping spore dimensions. The presence of conidiophores was not mentioned for specimens from Ghana and Kenya (Gryzenhout et al. 2005) and they were not present in specimens examined in this study.

\section{Taxonomy}

Comparisons of DNA sequences and morphology of the fungus from Cameroon with the genera in the Cryphonectriaceae revealed that the fungus from Cameroon represents a previously undescribed genus in the family. A new genus and the linked species are described as follows.

Aurifilum Begoude, Gryzenh. \& Jol. Roux, gen. Nov.

Etymology - The name is derived from the Latin Aureus (golden) and filum (thread) referring to the orange, confluent stromata found in the cracks on the bark of infected trees.

Ascostromata magna, plerumque sub cortice vel erumpentia, pulvinata vel pyriformia, subimmersa. Ascosporae hyalinae, fusoideae vel ellipsoideae, septo singulo mediano.

Conidiomata ascomatorum partes pro loculis conidialibus vel structuris solitariis, aurantiaca cum apertura ostiolari, sine collo atrato, late convexa, subimmersa. Conidiophorae cylindricae hyalinae non septatae, cellulae conidiogenae phialidicae basibus inflatis apicibus attenuatis, cellulae nonnullae cylindricae steriles, paraphysibus similes. Conidia minuta hyalina cylindrica vel allantoidea, non septata. Species typical A. marmelostoma Begoude et al.

Ascostromata large, usually beneath or erumpent through bark, pulvinate to pyriform, semiimmersed, orange, upper region eustromatic, lower region pseudostromatic, pseudoparenchymatous to prosenchymatous tissue. Perithecia valsoid, embedded in stroma, fuscous black, bases globose to 
subglobose, necks emerge at stromatal surface with black ostioles, surround with orange stromatal tissue to form papillae. Asci fusoid to ellipsoidal, floating freely in perithecial cavity, unitunicate with non-amyloid, refractive apical ring. Ascospores hyaline, fusoid to ellipsoidal, one median septum.

Conidiomata part of ascomata as conidial locules or as solitary structures, orange, without a neck, tissue around ostiolar opening darkened, broadly convex, semi-immersed, uni- to multilocular, even to convoluted lining, tissue mostly prosenchymatous with pseudoparenchymatous tissue towards the margin depending on the developmental stage of the structures. Conidiophores cylindrical, aseptate, hyaline, conidiogenous cells phialidic with inflated bases and attenuated apices, some cylindrical cells sterile similar to paraphyses. Conidia minute, hyaline, cylindrical to allantoid, aseptate, exuded through ostioles as orange droplets or tendrils.

Aurifilum marmelostoma Begoude, Gryzenh. \& Jol. Roux, sp. nov. MB 513488 Fig. 4

Etymology-The word "marmelo" is Greek for confectionary cooking practice using quinces with honey and from which the jam known as marmalade is derived. The name refers to the darkened stomatal (stoma $=$ mouth) opening of the conidiomata giving the impression that they are covered with jam.

Ascostromata in cortice gregaria vel singula, saepe in rimis confluentia, mediocria vel magna, 300.0-830.0 $\mu \mathrm{m}$ supra corticem 760.0-1050.0 $\mu \mathrm{m}$ diametro crescentia, plerumque sub cortice vel erumpentia, subimmersa, pulvinata vel pyriformia, aurantiaca. Ascosporae hyalinae, fusoideae vel ellipticae, septo singulo mediano apice attenuata $(9.0-)$ 10.0-12.0 $(-13.5) \times 3.0-4.0(-4.5) \mu \mathrm{m}$.

Conidiomata ascomatarum partes pro loculis conidialibus vel structuris solitariis, aurantiaca, sine collis, apertura ostiolari atrata, late convexa, subimmersa, usque ad $660.0 \mu \mathrm{m}$ supra superficiem corticis et $660.0 \mu \mathrm{m}$ lata. Conidia minuta hyalina cylindrica vel allantoidea non septata (3.0-) 3.5$4.5(-5.0) \times 1.0-1.5(-2.5) \mu \mathrm{m}$, pro guttulis vel cirrhis aurantiacis per aperturam in superficie stromatis exsudata.

Ascostromata on bark gregarious or single, often confluent in cracks, medium to large, ascostromata extending 300.0-830.0 $\mu \mathrm{m}$ high above the bark, 760.0-1050.0 $\mu \mathrm{m}$ diam, usually beneath or erumpent through bark, semi-immersed, pulvinate to pyriform, orange, upper region eustromatic, lower region pseudostromatic, pseudoparenchymatous to prosenchymatous tissue. Perithecia valsoid, up to nine per stroma, embedded in stroma at irregular levels with bases touching host tissue, fuscous black, bases globose to subglobose, 190.0-310.0 $\mu \mathrm{m}$ diam, perithecial walls 170.0 $275.0 \mu \mathrm{m}$ thick. Perithecial necks periphysate, black, 30.0-100.0 $\mu \mathrm{m}$ wide, emerging at stromatal surface as black ostioles, surrounded with orange stromatal tissue to form papillae, textura porrecta, extended necks up to $550.0 \mu \mathrm{m}$ long. Asci fusoid to ellipsoidal, floating freely in the perithecial cavity, unitunicate with non-amyloid, refractive apical rings, non-stipitate, 8-spored, (44.5-) 47.0$53.5(-61.0) \times(7.0-) 7.5-9.0(-10.5) \mu \mathrm{m}$. Ascospores hyaline, fusoid to ellipsoidal, one median septum with tapered apex, $\left(9.0^{-}\right) 10.0-12.0(-13.5) \times 3.0-4.0(-4.5) \mu \mathrm{m}$.

Conidiomata part of ascomata as conidial locules or as solitary structures, orange, necks absent, tissue around ostiolar openings darkened, broadly convex, semi-immersed, up to $660.0 \mu \mathrm{m}$ above the bark surface and up to $600.0 \mu \mathrm{m}$ in diam, uni- to multilocular, even to convoluted lining, locule 80.0-300.0 $\mu \mathrm{m}$ diam, tissue mostly prosenchymatous with pseudoparenchyma towards the margin depending on the developmental stage of the structure. Conidiophores cylindrical, aseptate, hyaline, (8.5-) 15.5-41.5 (-58.5) $\mu \mathrm{m}$ long, conidiogenous cells phialidic, sometimes with inflated bases, collarettes inconspicuous with attenuated apexes, $\left(2.0^{-}\right) 2.5-3.5(-4.5) \mu \mathrm{m}$ wide, long sterile cylindrical cells similar to paraphyses present, $(22.5-) 33.5-66.0(-89.0) \times 2.5-3.5(-4.0) \mu \mathrm{m}$. 
Conidia minute, hyaline, cylindrical to allantoid, aseptate, exuded through opening at stromatal surface as orange droplets or tendrils, $\left(3.0^{-}\right) 3.5-4.5(-5.0) \times 1.0-1.5(-2.5) \mu \mathrm{m}$.
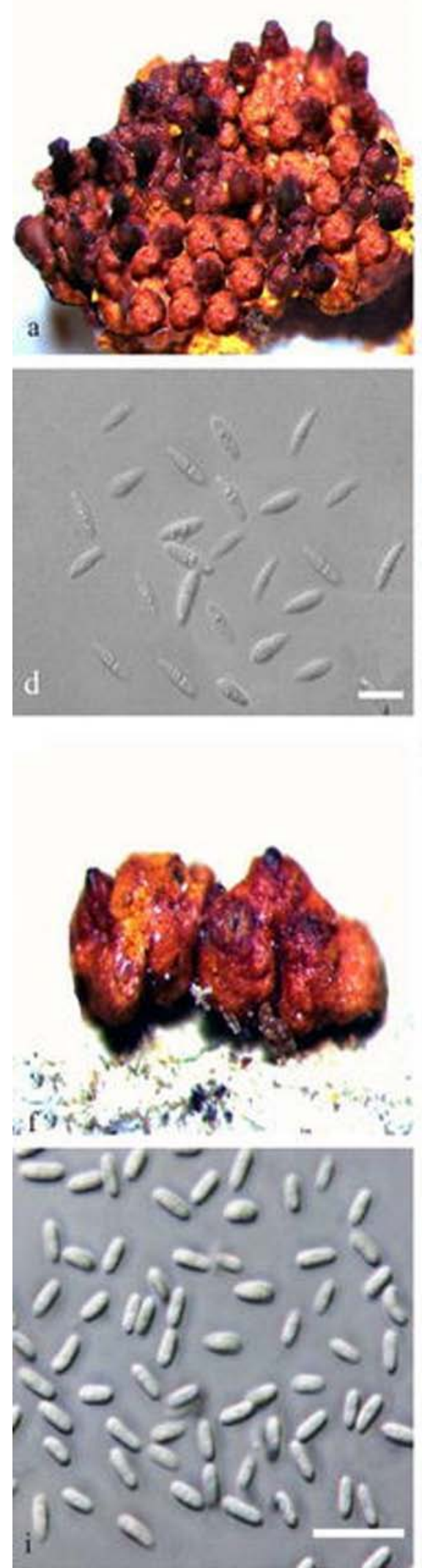
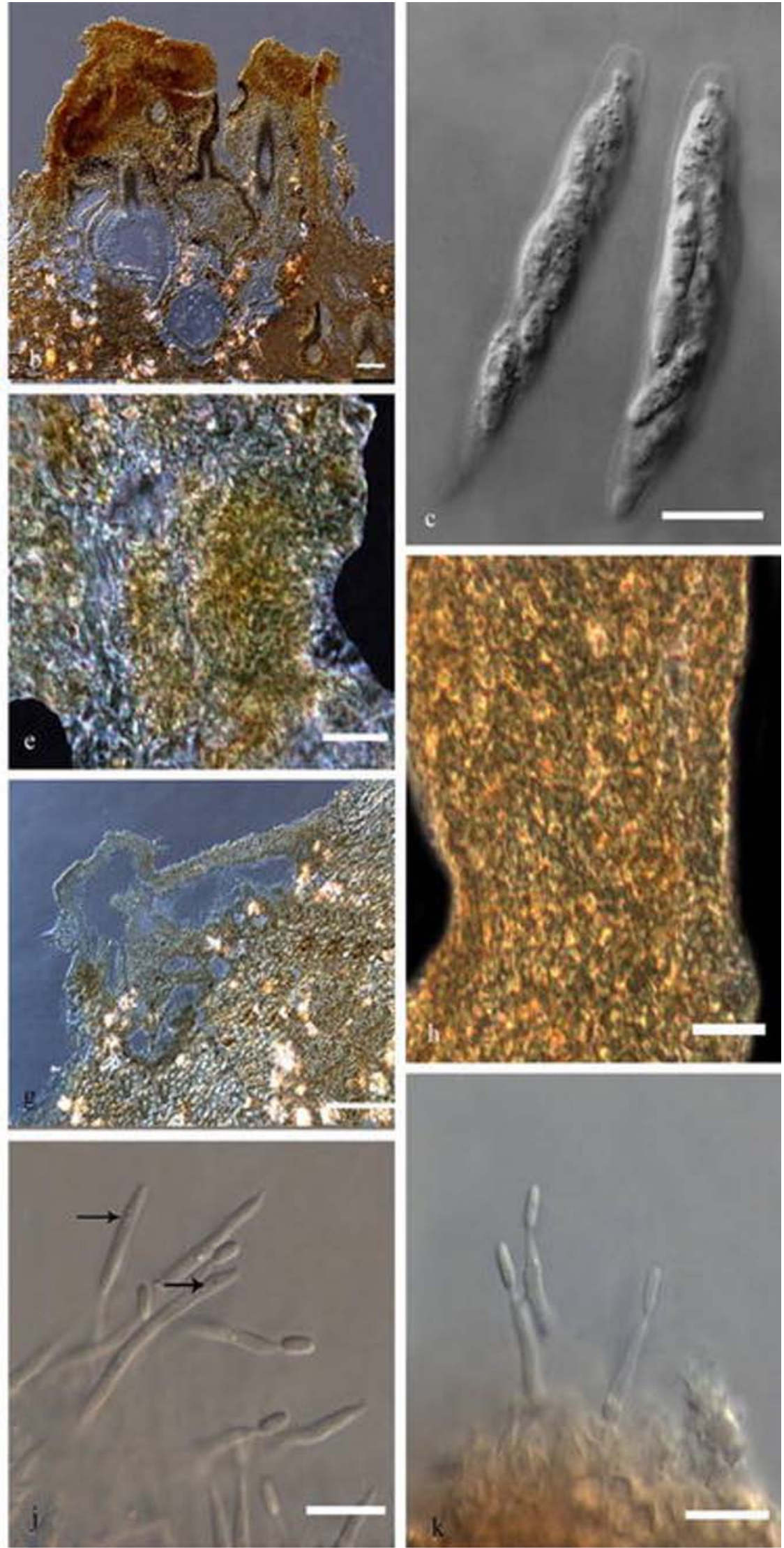

Fig. 4. Fruiting structures of Aurifilum marmelostoma. $\mathbf{a}$ orange ascostromata on bark; $\mathbf{b}$ vertical section through ascostromata; $\mathbf{c}$ ascus; $\mathbf{d}$ ascospores; $\mathbf{e}$ stromatic tissue of ascostromata; $\mathbf{f}$ conidiomata showing a black ostiolar opening; $\mathbf{g}$ vertical section though conidiomata; $\mathbf{h}$ stromatic 
tissue of conidiomata; $\mathbf{i}$ conidia; $\mathbf{j}$ conidiophores and sterile paraphyses (arrows); $\mathbf{k}$ conidiophores. Scale bars: $\mathbf{a}, \mathbf{d}, \mathbf{f}, \mathbf{i}, \mathbf{j}, \mathbf{k}=10 \mu \mathrm{m} ; \mathbf{c}, \mathbf{e}, \mathbf{g}, \mathbf{h}=20 \mu \mathrm{m} ; \mathbf{b}=50 \mu \mathrm{m}$.

Cultural characteristics - mycelium fluffy, slightly aerial, creamy white to pale luteous.

Conidiomata produced occasionally on old cultures. Optimum temperature of growth $25-30^{\circ} \mathrm{C}$, covering the $90 \mathrm{~mm}$ diameter Petri plate after 1 week in the dark. No growth at 10 and $35^{\circ} \mathrm{C}$.

Hosts-Terminalia mantaly H. Perrier, Terminalia ivorensis A. Chev.

Distribution —Cameroon: Kribi, Mbamalyo and Yaounde.

Specimens examined: Cameroon, Mbamalyo, bark of Terminalia ivorensis, Dec 2007, D. Begoude and J. Roux, PREM 60256-holotype, CMW28290/CBS124928 ex-type culture.

Additional specimens: Cameroon, Yaoundé, bark of dead branches of Terminalia mantaly, Dec 2007, D. Begoude and J. Roux. PREM 60257-Paratype, living cultures CMW28285/CBS124929; Mbalmayo: isolated from bark of Terminalia ivorensis, Dec 2007, D. Begoude and J. Roux. Paratype, living cultures CMW28288/CBS124930, CMW28592, CMW28289. The specimens, IMI 288729 and IMI 187898 obtained from Terminalia spp. in Ghana and Kenya, respectively, were also used, but could not be sequenced.

To facilitate identification of this genus, the dichotomous key presented by Gryzenhout et al. (2009) was updated to include this fungus. In this key, A. marmelostoma is compared with all members of the Cryphonectriaceae including those with dark fruiting bodies.

This key is based on characteristics of both the anamorph and teleomorph (key follows below).

\section{Pathogenicity}

Six weeks after inoculation, all isolates of $A$. marmelostoma yielded visible stem cankers on $T$. mantaly trees (Fig. 5). Analysis of variance showed that brown lesion lengths on the cambium for all isolates were significantly different $(\mathrm{P}<0.0001)$ to those associated with the negative control (Fig. 5). Isolate CMW28290 from T. ivorensis, was the most virulent and produced significantly longer lesions in the cambium than the other isolates. Orange-colored fruiting bodies were observed on the brown lesions produced by all the isolates, and these provided the basis to confirm the association of $A$. marmelostoma with the brown lesions resulting from inoculation. In contrast, all control inoculations did not result in any brown lesions, with all of them having developed callus tissue and sealing of the inoculation wound.

\section{Discussion}

The Cryphonectriaceae was described as a family to accommodate fungal species previously treated in the Cryphonectria-Endothia complex (Gryzenhout et al. 2006a). This study records the discovery of a previously unknown genus in the Cryphonectriaceae with a single species. Comparisons of DNA sequences of isolates representing all the genera in the Cryphonectriaceae suggest that this fungus represents a new taxon, for which the name Aurifilum marmelostoma was provided. 
1a. Orange conidiomata 2

1b. Black conidiomsta 9

2a. Conidiomata pulvinate, ascospores 3 septate or aseptate

2b. Coridiomata conical $\alpha$ rostrate or pyrif $\alpha \mathrm{rm}$ or 6 convex, with or without a neck, ascospores septate

33. Ascospores septate 4

3b. Ascospores aseptate 5

4a. Stromata strongly developed, erumpent, Cryphonectria semi-immersed, usually no paraphyses

4b. Stromata small to medium, semi- Microthia immersed to superficial, per aphyses present

5a. Stromata strongly developed, large,

Endothio erumpent, mostly superficial, numerous conidial beules, no paraphyses in conidial locules

5b. Stromata small to medium, semiimmersed, few conidial beules or one convoluted locule, paraphyses in conidial locules

6a. Conidiomsta with necks, ascospores single septate

6b. Conidiomata without necks, ascospores 8 septate

7a. Conidiomata rostrate, white shesth of tissue surrounding perithecial necks when sectioned bngitudinally

7b. Conidiomata rostrate to pyriform with large base, neck attenuated or not, te komorph still unknown

8a. Conidiomata conical without attenuated Amphilogia necks, uniformly or ange, ascospores 1 to 3-septate

8b. Conidiomata convex, with blackened ostiolar openings, ascospores 1-septate

9a. Conidiomsta uniformly blsck

A urifilum

9b. Conidiomata with orange neck, 9 teleomorph still unknown

Hobcryphia

Ursic olüum

Conidiomsta pulvinate to pyriform with attemuated neck, bsse tissue of textura globubsa, perithecial necks long and covered with dark tissue

10b. Conidiomata pulvinate or conical,

Celoporthe oceasionally with short necks, base tissue prosenchymatous, perithecial necks short and of same color as stroma 


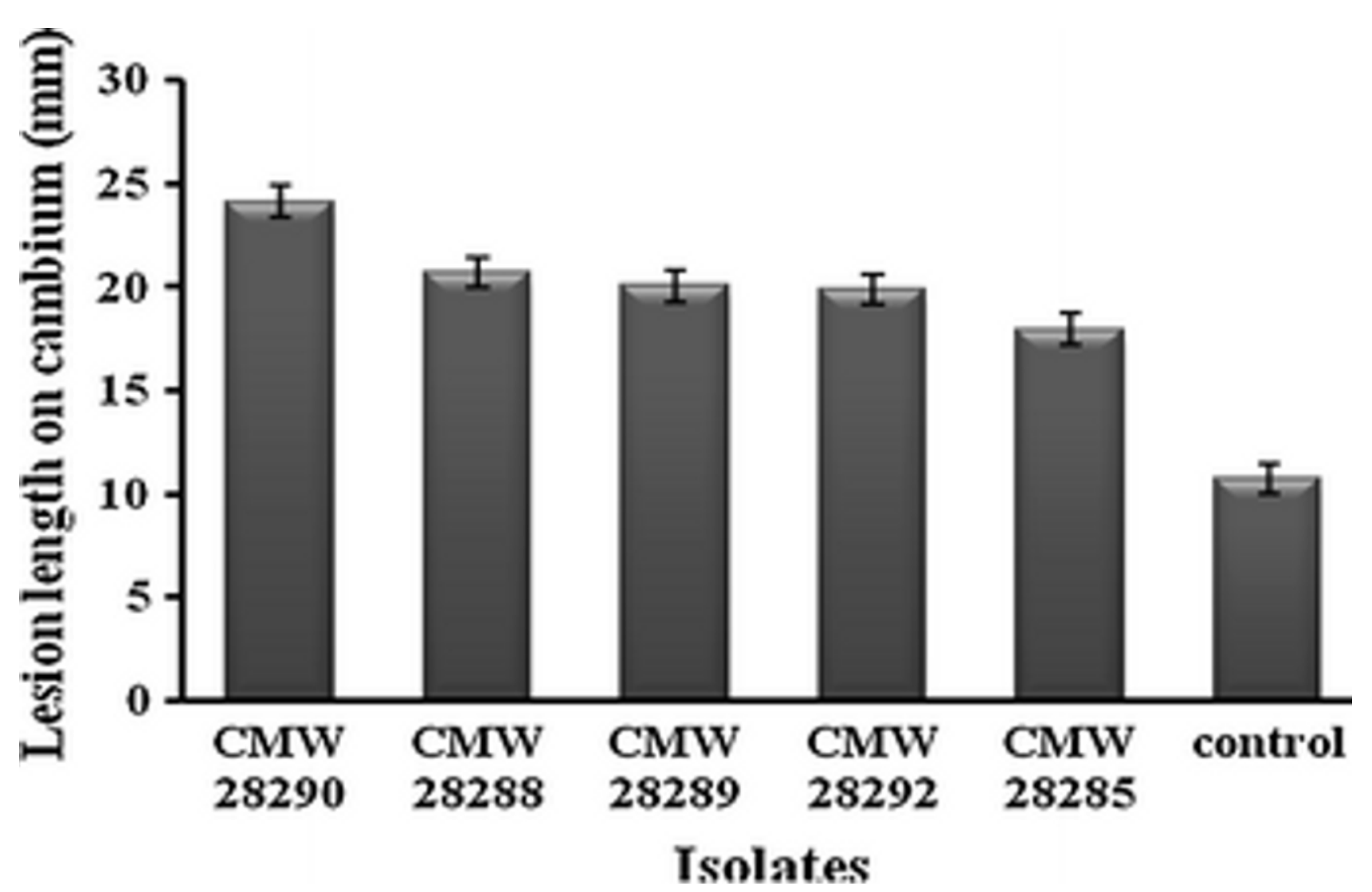

Fig. 5. Mean lesion lengths $(\mathrm{mm})$ on the cambium for each Aurifilum marmelostoma isolate 6 weeks after inoculation on Terminalia mantaly $(\mathrm{P}<0.0001)$.

Aurifilum marmelostoma shares characteristics with several taxa in the Cryphonectriaceae, especially those with uniformly orange fruiting bodies. While the teleomorph state was especially similar to those of other Cryphonectriaceae, a suite of characters in the anamorph of $A$. marmelostoma differentiate this species. The broadly convex conidiomata without necks were similar but wider than conidiomata of Amphilogia and Rostraureum, and different in shape from the conidiomata of Cryphonectria, Endothia, Holocryphia and Microthia that have pulvinate structures. Furthermore, the ostiolar openings of A. marmelostoma were often darkened while this has not been observed for any other anamorph in the Cryphonectriaceae. The presence of long cylindrical cells, similar to paraphyses (Walker et al. 1985; Venter et al. 2002), provides additional characteristic to differentiate the anamorph of $A$. marmelostoma from the anamorphs of morphologically similar Cryphonectriaceae.

The morphological comparison of specimens previously obtained from $T$. ivorensis in Ghana and Kenya with those isolated from Terminalia spp. in Cameroon revealed some similarities in their teleomorph states. However, long sterile cells, or paraphyses, present in anamorphs of the Cameroonian specimens, were not observed in the other African specimens. Because molecular evidence to support morphological findings is not available, it is difficult to provide a conclusive taxonomic position to the specimens associated with $T$. ivorensis in the other African countries.

Aurifilum marmelostoma produced more ascostromata on the bark of Terminalia spp. than asexual fruiting structures. This inconsistency in the production of sexual and asexual fruiting structures is well-known in other species of the Cryphonectriaceae. For example, Chr. austroafricana in South Africa produces ascostromata on native Syzygium spp., but rarely produces these structures on nonnative Eucalyptus spp. (Van Heerden and Wingfield 2001; Heath et al. 2006; Nakabonge et al. 2006b). However, in countries such as Malawi, Mozambique and Zambia, Chr. austroafricana produced both sexual and asexual structures on Syzygium spp. and Eucalyptus spp. (Nakabonge et al. 2006b). Surveys in other regions and on hosts other than Terminalia spp. will thus be necessary 
to determine whether the production of more sexual than asexual structures is consistent regardless of host or location. This is important since it is the anamorph structures that distinguish $A$. marmelostoma from related genera and species of Cryphonectriaceae with orange fruiting bodies.

Results of the pathogenicity trials showed that all isolates were pathogenic to young T. mantaly trees. This result and the consistent association of A. marmelostoma with disease symptoms on $T$. ivorensis suggest that the fungus is a pathogen of Terminalia trees. However, pathogenicity tests on T. ivorensis will be needed to provide conclusive evidence of its impact and threat to these important native trees. Furthermore, A. marmelostoma caused lesions on T. mantaly during nursery inoculations, but on mature trees the fungus was present only on cut and dying branches lying on the ground.

Members of the Cryphonectriaceae are well known to occur on Myrtales in Africa. Prior to this study, three genera, including Celoporthe, Chrysoporthe and Holocryphia, were reported infecting trees in the Combretaceae, Heteropyxidaceae, Melastomataceae and the Myrtaceae (all Myrtales) in the sub-Saharan part of the continent (Ofosu-Asiedu and Cannon 1976; Gibson 1981; Myburg et al. 2002; Roux et al. 2003; Heath et al. 2006; Nakabonge et al. 2006b). Although members of the Cryphonectriaceae have been reported from Africa regularly (Gibson 1981; Conradie et al. 1990; Myburg et al. 2002; Gryzenhout et al. 2003; Roux et al. 2003, 2005; Nakabonge et al. 2006a, b), it is clear that their geographical and host distribution on the continent deserves further study.

\section{Acknowledgments}

We thank the DST/NRF Centre of Excellence in Tree Health Biotechnology (CTHB), the University of Pretoria, South Africa for financial support. We also recognise the Institute of Agricultural Research for Development (IRAD), the International Institute of Tropical Agriculture (IITA) and the Yaoundé Urban Council in Cameroon for logistic support and Mr Onana Dieudonne and other colleagues at IRAD for assistance and guidance regarding tree identification. Dr. Hugh Glen provided the Latin descriptions and suggested names for the fungus for which we are most grateful.

\section{Literature Cited}

Anagnostakis SL (1987) Chestnut blight: the classical problem of an introduced pathogen. Mycologia 79:23-37.

Anagnostakis SL (2001) American chestnut sprouts survival with biological control of the chestnutblight fungus populations. For Ecol Manag 152:225-233.

Batawila K, Kokou K, Koumaglo K, Gbéassor M, de Foucault B, Bouchet PH, Akpagana K (2005) Antifungal activities of five Combretaceae used in Togolese traditional medicine. Fitoterapia 76:264-268.

Castlebury LA, Rossman AY, Jaklitsch WJ, Vasilyeva LN (2002) A preliminary overview of the Diaporthales based on large subunit nuclear ribosomal DNA sequences. Mycologia 94:1017-1031.

Conradie E, Swart WJ, Wingfield MJ (1990) Cryphonectria canker of Eucalyptus, an important disease in plantation forestry in South Africa. South Afr For J 152:43-49.

Felsenstein J (1985) Confidence limits on phylogenies: an approach using the bootstrap. Evolution 39:783-791. 
Gibson IAS (1981) A canker disease of Eucalyptus new to Africa. FAO For Genet Res Info 10:2324.

Glass NL, Donaldson GC (1995) Development of primer sets designed for use with the PCR to amplify conserved genes from filamentous ascomycetes. Appl Environ Microbiol 61:1323-1330.

Gryzenhout M, Eisenberg BE, Coutinho TA, Wingfield BD, Wingfield MJ (2003) Pathogenicity of Cryphonectria eucalypti to Eucalyptus clones in South Africa. For Ecol Manag 176:427-437.

Gryzenhout M, Myburg H, Van der Merwe NA, Wingfield BD, Wingfield MJ (2004) Chrysoporthe, a new genus to accommodate Cryphonectria cubensis. Stud Mycol 50:119-142.

Gryzenhout M, Myburg H, Wingfield BD, Montenegro F, Wingfield MJ (2005) Rostraureum tropicale gen. sp. nov. (Diaporthales) associated with dying Terminalia ivorensis in Ecuador. Mycol Res 109:1029-1044.

Gryzenhout M, Myburg H, Wingfield BD, Wingfield MJ (2006a) Cryphonectriaceae (Diaporthales), a new family including Cryphonectria, Chrysoporthe, Endothia, and allied genera. Mycologia 98:239-249.

Gryzenhout M, Myburg H, Hodges CS, Wingfield BD, Wingfield MJ (2006b) Microthia, Holocryphia and Ursicullum, three new genera on Eucalyptus and Coccoloba for fungi previously known as Cryphonectria. Stud Mycol 55:35-52.

Gryzenhout M, Wingfield BD, Wingfield MJ (2009) Taxonomy, phylogeny, and ecology of bark infecting and tree killing fungi in the Cryphonectriaceae. APS Press, St. Paul, Minnesota.

Heath RN, Gryzenhout M, Roux J, Wingfield MJ (2006) Discovery of the canker pathogen Chrysoporthe austroafricana on native Syzygium spp. in South Africa. Plant Dis 90:433-438.

Heiniger U, Rigling D (1994) Biological control of chestnut blight in Europe. Ann Rev Phytopathol 32:581-599.

Hillis DM, Huelsenbeck JP (1992) Signal, noise, and reliability in molecular phylogenetic analyses. J Hered 83:189-195.

Hodges CS (1980) The taxonomy of Diaporthe cubensis. Mycologia 72:542-548.

Hodges CS, Ferreira FA (1981) Korunomyces, a new genus of fungi imperfecti from Brazil. Mycologia 73:334-342.

Huelsenbeck JP, Ronquist F (2001) MrBayes: Bayesian inference of phylogenetic trees. Bioinformatics 17:754-755.

Kamgan NG, Jacobs K, De Beer ZW, Wingfield MJ, Roux J (2008) Ceratocystis and Ophiostoma species including three new taxa, associated with wounds on native South African trees. Fungal Divers 29:37-59.

Kamtchouing P, Kahpui SM, Djomeni Dzeufiet PD, Tedong L, Asongalem EA, Dimo T (2006) Anti-diabetic activity of methanol/methylene chloride stem bark extracts of Terminalia superba and Canarium schweinfurthii on streptozotocin-induced diabetic rats. J Ethnopharmacol 104: 306-309. 
Katoh K, Kuma K, Toh H, Miyata T (2005) MAFFT version 5: improvement in accuracy of multiple sequence alignment. Nucleic Acids Res 33:511-518.

Laird SA (1999) The management of forests for timber and non-timber forest products in central Africa. In: Sunderland TCH, Clark LE, Vantomme P (eds) Current research issues and prospects for conservation and development of nonwood forest products of Central Africa. FAO, Rome, pp 5160 .

Lamb AFA, Ntima OO (1971) Terminalia ivorensis: fast growing timber trees of the lowland tropics No. 5. Commonwealth Forestry Institute, Oxford.

Lumbsch HT, Huhndorf SM (2007) Notes on ascomycete systematics. Nos. 4408-4750. Myconet 13:59-99.

Micales JA, Stipes RJ (1987) A reexamination of the fungal genera Cryphonectria and Endothia. Phytopathology 77:650-654.

Möller EM, Bahnweg G, Sandermann H, Geiger HH (1992) A simple and efficient protocol for isolation of high molecular weight DNA from filamentous fungi, fruit bodies, and infected plant tissues. Nucleic Acids Res 20:6115-6116.

Myburg H, Gryzenhout M, Heath R, Roux J, Wingfield BD, Wingfield MJ (2002) Cryphonectria canker on Tibouchina in South Africa. Mycol Res 106:1299-1306.

Myburg H, Gryzenhout M, Wingfield BD, Stipes RJ, Wingfield MJ (2004) Phylogenetic relationships of Cryphonectria and Endothia species, based on DNA sequence data and morphology. Mycologia 96:990-1001.

Nakabonge G, Gryzenhout M, Roux J, Wingfield BD, Wingfield MJ (2006a) Celoporthe dispersa gen. et sp. nov. from native Myrtales in South Africa. Stud Mycol 55:255-267.

Nakabonge G, Roux J, Gryzenhout M, Wingfield MJ (2006b) Distribution of Chrysoporthe canker pathogens on Eucalyptus and Syzygium spp. in Eastern and Southern Africa. Plant Dis 90:734-740.

Norgrove L, Hauser S (2002) Measured growth and tree biomass estimates of Terminalia ivorensis in the 3 years after thinning to different stand densities in an agrisilvicultural system in southern Cameroon. For Ecol Manag 166: 261-270.

Nylander JAA (2004) MrModeltest 2.3. Program distributed by the author. Evolutionary Biology Centre, Uppsala University.

Ofosu-Asiedu A, Cannon P (1976) Terminalia ivorensis decline in Ghana. Pest Art News Sum 22:239-242.

Rayner RW (1970) A mycological colour chart. Commonwealth Mycological Institute and British Mycological Society, Kew, Surrey.

Rossman AY, Farr DF, Castlebury LA (2007) A review of the phylogeny and biology of the Diaporthales. Mycoscience 48:135-144.

Roux J, Myburg H, Wingfield BD, Wingfield MJ (2003) Biological and phylogenetic analysis suggest that two Cryphonectria species cause cankers of Eucalyptus in Africa. Plant Dis 87:1329- 
Roux J, Meke G, Kanyi B, Mwangi L, Mbaga A, Hunter GC, Nakabonge G, Heath RN, Wingfield MJ (2005) Diseases of plantation forestry tree species in eastern and southern Africa. South Afr J Sci 101:409-413.

Swofford DL (1998) PAUP. Phylogenetic analysis using parsimony (and other methods). Version 4. Sinaur Associates, Sunderland, Massachusetts.

Tamura K, Dudley J, Nei M, Kumar S (2007) MEGA4: Molecular Evolutionary Genetics Analysis (MEGA) software version 4.0. Mol Biol Evol 24:1596-1599.

Thiombiano A, Schmidt M, Kreft H, Guinko S (2006) Influence du gradient climatique sur la distribution des espe'ces de Combretaceae au Burkina Faso (Afrique de l'ouest). Candollea 61:189213.

Van Heerden SW, Wingfield MJ (2001) Genetic diversity of Cryphonectria cubensis in South Africa. Mycol Res 105:94-99.

Venter M, Myburg H, Wingfield BD, Coutinho TA, Wingfield MJ (2002) A new species of Cryphonectria from South Africa and Australia, pathogenic on Eucalyptus. Sydowia 54:98-119.

Walker TJ, Old KM, Murray DIL (1985) Endothia gyrosa on Eucalyptus in Australia with notes on some other species of Endothia and Cryphonectria. Mycotaxon 23:353-370.

White TJ, Bruns TD, Lee S, Taylor J (1990) Amplification and direct sequencing of fungal ribosomal RNA genes for phylogenetics. In: CR P, Innis MA, Gelfand DH, Sninsky JJ, White TJ (eds) Protocols: a guide to methods, applications. Academic Press, San Diego, pp 315-322.

Wingfield MJ (2003) Daniel McAlpine Memorial Lecture. Increasing threat of diseases to exotic plantation forests in the Southern Hemisphere: lessons from Cryphonectria canker. Australas Plant Pathol 23:133-139. 